\title{
Penerapan Media Komik Sains untuk Meningkatkan Minat dan Hasil Belajar Siswa pada Konsep Gejala Pemanasan Global di SMA Negeri 10 Bandung
}

\author{
Elly Cholisoh \\ SMA Negeri 10 Bandung, Kota Bandung - Provinsi Jawa Barat \\ Corresponding Author. Email: echolisoh@gmail.com
}

\begin{abstract}
The purpose of this study was to increase students' interest and learning outcomes in the concept of global warming symptoms through the application of science comics.. This research method used classroom action research conducted in 2 cycles and carried out in SMA Negeri 10 Bandung by taking a sample of 30 students of class XI IPA. The instruments used in this study were questionnaires and tests. The data from the research results were obtained through the pre-test and post-test in the first cycle with an average of 64.93 and 66.83 with the incomplete category, while in the second cycle the average score for the pre-test was 74.37 and the post-test was 88.66 with the complete category. . The results of data analysis showed that learning outcomes increased, while the results of the student interest questionnaire showed $92.59 \%$ of students were very interested and $7.41 \%$ of students were interested. The collected data were also analyzed by calculating the $\mathrm{N}$-gain and t-test resulting in the $\mathrm{N}$-gain in Cycle $\mathrm{I}=0.05$ in the low category, while Ngain in the second cycle $=0.56$ in the moderate category. The results of the t-test calculation show that $t \_h i t=9.69$ while $t \_t a b=2.05$ so that $t \_$(hit $>$) $t \_t a b$. Based on the research data, it can be concluded that science comics can increase students' interest and learning outcomes in the concept of global warming symptoms.
\end{abstract}

Abstrak: Tujuan penelitian ini adalah untuk meningkatkan minat dan hasil belajar siswa pada konsep gejala pemanasan global melalui penerapan komik sains. Metode penelitian ini menggunakan penelitian tindakan kelas yang dilakukan sebanyak 2 siklus dan dilaksanakan di SMA Negeri 10 Bandung dengan mengambil sampel sebanyak 30 orang siswa kelas XI IPA. Instrumen yang digunakan dalam penelitian tersebut adalah angket dan tes. Data hasil penelitian diperoleh melalui pre test dan post test pada siklus I rata-rata 64,93 dan 66,83 dengan kategori belum tuntas, sedangkan pada siklus II didapat nilai rata rata pre test 74,37 dan post test 88,66 dengan kategori tuntas. Hasil analisis data menunjukkan bahwa hasil belajar meningkat, sedangkan hasil angket minat siswa menunjukkan $92,59 \%$ siswa sangat minat dan $7,41 \%$ siswa minat. Data yang terkumpul dianalisis juga dengan perhitungan $\mathrm{N}$-gain dan uji-t menghasilkan $\mathrm{N}$-gain Siklus I = 0,05 kategori rendah sedangkan Ngain pada siklus II $=0,56$ kategori sedang. Hasil perhitungan uji-t bahwa $t_{\text {hit }}=9,69$ sedang $t_{t a b}=2,05$ sehingga $t_{\text {hit }}>t_{t a b}$. Berdasarkan data hasil penelitian tersebut dapat disimpulkan bahwa komik sains dapat meningkatkan minat dan hasil belajar siswa pada konsep gejala pemanasan global.

How to Cite: Cholisoh, E. (2021). Penerapan Media Komik Sains untuk Meningkatkan Minat dan Hasil Belajar Siswa pada Konsep Gejala Pemanasan Global di SMA Negeri 10 Bandung. Jurnal Teknologi Pendidikan : Jurnal Penelitian dan Pengembangan Pembelajaran, 6(1). doi:https://doi.org/10.33394/jtp.v6i1.3603

do

https://doi.org/10.33394/jtp.v6i1.3603

This is an open-access article under the CC-BY-SA License.

\section{Pendahuluan}

Salah satu bidang studi yang mendukung perkembangan ilmu pengetahuan dan teknologi adalah Fisika. Oleh karena itu, Fisika merupakan bidang studi yang menduduki 
peranan penting dalam pendidikan. Menurut Badan Standar Nasional Pendidikan (BNSP) dijelaskan bahwa tujuan diberikan pelajaran Fisika pada setiap jenjang pendidikan dasar dan menengah agar siswa dapat menggunakan fisika sebagai cara bernalar (berpikir logis, analitis, sistematis, kritis, kreatif komunikatif dan kolaborasi). Fisika merupakan cara mencari tahu tentang alam secara sistematis untuk menguasai pengetahuan, fakta, konsep, prinsip, proses penemuan dan memiliki sikap ilmiah (Soekarman, 2021).

Lembaga penyelenggara pendidikan dituntut untuk terus meningkatkan kualitas pembelajaran dan proses penyelenggaraan pendidikan, sehingga perlu diterapkan suatu metode pencapaian kualitas pembelajaran yang dapat dilakukan melalui lembaga pendidikan dan juga melalui indvidu seorang guru. Guru dalam konteks pendidikan mempunyai peranan yang besar sehingga menuntut guru mempunyai strategi dan kreativitas dalam proses belajar mengajar. Kenyataan di lapangan bahwa pendidikan di sekolah lebih berorientasi pada pembelajaran fisika perlu diperbaiki guna mendidik para siswa agar tumbuh menjadi orang orang yang aktif dan kreatif dalam mempelajari ilmu fisika (Munandar, 2005). Usaha ini dimulai dengan pembenahan proses pembelajaran yang dilakukan guru yaitu dengan menawarkan suatu pendekatan, model, metode dan media pembelajaran (Suarni et al, 2021; Purwati, 2019; Setiarini, 2016)

Menurut Hamalik (2004) kemampuan yang selama ini yang harus dikuasai guru yang akan lebih dituntut aktualisasinya, misalnya kemampuannya dalam merencanakan pembelajaran dan merumuskan tujuan, mengelola kegiatan individu, menggunakan multi metode dan memanfaatkan media pembelajaran, berkomunikasi interaktif dengan baik. Selain itu, untuk mendapatkan proses belajar mengajar yang lebih baik, maka guru dituntut untuk mampu mengembangkan media pembelajaran. Media pembelajaran adalah segala sesuatu yang dapat digunakan untuk menyampaikan pesan atau informasi dalam proses belajar mengajar sehingga dapat merangsang perhatian dan minat serta hasil belajar (Arsyad, 2011). Media pembelajaran yang digunakan dalam proses belajar mengajar memiliki peranan penting dalam menentukan keberhasilan dalam belajar (Daryanto, 2010). Oleh karena itu, guru dituntut agar dapat menerapkan media pembelajaran yang efektif dan efisien yang dapat meningkatkan hasil belajar mengajar. Manfaat dari media pembelajaran untuk meningkatkan suasana belajar yang lebih kondusif dengan lebih melibatkan aspek-aspek kecerdasan siswa dengan kata lain siswa diarahkan untuk melakukan aktivitas pembelajaran mandiri dengan pengawasan secara proposional oleh guru (Musfiqon, 2012).

Berdasarkan pengamatan di kelas XI IPA I SMAN 10 Bandung pada pelajaran fisika masih ditemui gejala-gejala dalam pembelajaran yaitu siswa kurang respon terhadap penjelasan guru, siswa tidak menulis atau mencatat penjelasan guru, siswa masih lemah dalam mengingat, siswa tidak efektif dalam berfikir serta siswa masih belum maksimal dalam mengerjakan tugas atau latihan. Berdasarkan gejala gejala tersebut dapat dikatakan bahwa minat siswa dalam belajar fisika masih cenderung rendah, sehingga dibutuhkan terciptanya suasana belajar yang menyenangkan yang dipengaruhi dengan penggunaan media pembelajaran yang tepat. Hal ini dapat berdampak terhadap semakin rendahnya tingkat hasil belajar siswa terhadap pelajaran fisika. Peneliti mencoba menggunakan perangkat pembelajaran berupa media pembelajaran yang sedkit berbeda dari yang lainnya. Media tersebut berupa komik.

Komik merupakan sebuah bahan bacaan yang disukai oleh berbagai kalangan usia dari yang anak anak sampai dengan yang dewasa. Penyajian sederhana dan penceritaan sebuah situasi dituangkan dalam bentuk gambar dapat lebih mudah untuk membangkitkan gairah dan minat siswa untuk nmembacanya. Komik biasanya dilengkapi dengan adanya 
tokoh, latar belakang, balon baca, panel (kotak yang memisahkan antara adegan satu dengan adegan lainnya) narasi dan efek warna yang semakin membuat cerita lebih hidup. Komik sains yang akan dibuat oleh siswa secara berkelompok, dengan tujuan bahasa yang digunakan oleh siswa dipahami juga oleh siswa lainnya (Nurlatipah et al., 2015; Ahsani, 2015). Komik ini diharapkan dapat membantu siswa untuk lebih memahami materi fisika khususnya gejala pemanasan global yang sering kita dapatkan dalam kehidupan sehari hari. Dengan menggunakan bahasa, gambar dan cerita yang disesuaikan dengan situasi dan kondisi yang ada membuat siswa lebih mudah dalam menyerap informasi yang disampaikan oleh guru (Lestari, 2009).

Adapun tujuan dilakukannya penelitian ini adalah untuk meningkatkan minat dan hasil belajar siswa pada konsep gejala pemanasan global melalui penerapan komik sains di SMA Negeri 10 Bandung.

\section{Metode Penelitian}

Metode yang digunakan dalam penelitian ini adalah metode tindakan kelas. Penelitian tindakan kelas terdiri dari tiga langkah utama yaitu rencana tindakan, pelaksanaan tindakan, dan refleksi. Pelaksanaan tahap implementasi pembelajaran gejala pemanasan global menggunakan media komik sains, dilakukan dengan 2 siklus sesuai dengan langkah PTK. Populasi dalam penelitian ini adalah semua siswa kelas XI IPA I SMAN 10 Bandung. Sampel dalam penelitian ini adalah siswa kelas XI IPA 1 SMAN 10 Bandung, yang berjumlah 30 siswa sebagai respondennya.

Pengumpulan data dalam penelitian ini dilakukan melalui angket, observasi, pre-test dan post test. Teknik pengolahan data dengan menggunakan point to view yaitu;

$$
\mathrm{P}=\frac{f}{N} \times 100 \%
$$

Sehingga dapat diperoleh gambaran hasil pencapaian belajar antara siklus I yang menggunakan media konvensional dengan siklus II yang menggunakan media komik sains.

\section{Hasil Penelitian dan Pembahasan}

Hasil dari kegiatan ini diukur melalui data primer yang berupa hasil pre-test dan post tes dan juga data sekunder yang meliputi hasil analisa jawaban siswa, observasi, dan refleksi yang dilakukan pada kegiatan pembelajaran. Berikut uraian analisis kuantitatif dan kualitatif deskripsi perkembangan siswa setelah pembelajaran penggunaan media komik sains dalam belajar.

Tabel 1. Data Analisa Kuantitatif

\begin{tabular}{|l|l|l|l|}
\hline No & \multicolumn{1}{|c|}{ Item } & Pre Test & Post Test \\
\hline 1 & Siklus 1 & 64,93 & 66,83 \\
\hline 2 & Siklus 2 & 74,37 & 88,66 \\
\hline
\end{tabular}

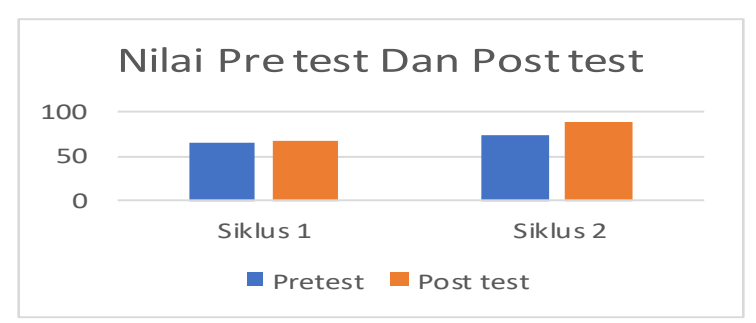

Grafik 1. Data Penilaian Kuantitatif 
Tabel 2. Data Perkembangan Pengetahuan Siswa

\begin{tabular}{||l|c|c|c|c|}
\hline Keterangan & Pre test & $\begin{array}{l}\text { Jumlah } \\
\text { siswa }\end{array}$ & Post test & $\begin{array}{l}\text { Jumlah } \\
\text { siswa }\end{array}$ \\
\hline $\begin{array}{l}\text { Nilai } \\
\text { tertinggi }\end{array}$ & 90 & 2 & 100 & 9 \\
\hline $\begin{array}{l}\text { Nilai } \\
\text { terendah }\end{array}$ & 33 & 1 & 60 & 1 \\
\hline Rerata & $\ldots \ldots$ & & $\ldots \ldots$ & \\
\hline
\end{tabular}

Berdasarkan data diatas, tingkat pengetahuan yang diperoleh mengalami peningkatan cukup tinggi. Hal ini menunjukkan bahwa peningkatan nilai yang diperoleh siswa, menunjukkan bahwa media komik sains dapat meningkatkakan hasil belajar siswa.

\section{Analisa Kualitatif}

Sebelum proses belajar mengajar berlangsung,siswa diberi pre test tentang gejala pemanasan global. Kemudian diteruskan dengan kegiatan belajar mengajar dengan menggunakan model pembelajaran jigsaw, dan metode diskusi, observasi, angket serta LKS tentang gejala pemanasan global. Berdasarkan kegiatan pembelajaran yang dilakukan pada siklus I, dimana siswa pada siklus I memaparkan ide cerita tentang gejala pemanasan global kaitan dengan akan dibuat media pembelajaran yaitu komik sains. Siswa dapat mencari sumber dari buku paket,internet atau sumber sumber lain. Diakhir pelajaran pada siklus I ini siswa menyelesaikan post test.

Sedangkan pada siklus 2 siswa perkelompok sudah membuat komik sains yang dibuat berdasarkan banyaknya anggota kelompok yang terdiri dari 6 bahasan yaitu 1). Pengertian gejala pemanasan global. 2) Penyebab gejala pemanasan global 3). Dampak pemanasan global. 4). Proses terjadinya pemanasan global. 5). Pengendalian pemanasan global. 6). Latihan soal soal tentang gejala pemanasan global. Tiap bahasan materi dipresentasikan oleh perwakilan kelompok masing-masing, dan kelompok lain memperhatikan dan mereview kembali cerita yang disampaikan melalui komik sains. Dan diakhir cerita siswa latihan soal gejala pemanasan global serta menyelesaikan post test.

Berdasarkan data observasi yang dilakukan oleh salah seorang guru, didapat data bahwa didalam siklus I ini, siswa masih mendapat kesulitan dalam mencari bahan materi untuk di diskusikan. Dan guru mendapat kesulitan dalam membagi kelompok dan mengarahkan siswa untuk berdiskusi. Data siswa dari angket tentang minat siswa dalam belajar fisika dengan menggunakan media komik sains didapat:

\begin{tabular}{|l|l|l|l|}
\hline No & Jumlah Siswa & SM & M \\
\hline 1 & 30 Orang & 25 & 5 \\
\hline
\end{tabular}

Data yang terkumpul dianalisis dengan menggunakan perhitungan uji-t dan $\mathrm{N}$ gain ternormalisasi dan didapat siklus I $\mathrm{N}$ gain $=0,05$ kategori rendah sedang siklus $2 \mathrm{~N}$ gain $=$ 0,56 kategori sedang dan didapat $t_{\text {hit }}=9,69$ kategori sedang dan $t_{\text {tab }}=2,05$ maka $t_{\text {hit }}$ $>t_{t a b}$ artinya penelitian ini berhasil. Pembelajaran dengan menggunakan media komik sains secara tidak langsung, siswa mengembangkan ketrampilan berupa kritis, kreatif, kolaboratif dan komunikatif sesuai dengan tuntutan abad 21. 


\section{Kesimpulan}

Kesimpulan yang diperoleh dari hasil penelitian ini adalah media komik sains dapat meningkatkan minat dan hasil belajar siswa. Hal ini dapat terlihat pada peningkatan presentase pre test dan post test sebesar $88,93 \%$ dan minat siswa terhadap pelajaran fisika dengan menggunakan media komik sains sebesar 92,59\% kategori sangat minat dan 7,41\% kategori minat. Melalui pengumpulan data analisis kuantitafif dan analisis kualitatif dengan menggunakan perhitungan uji $-\mathrm{t}$ dan $\mathrm{N}$ gain ternormalisasi didapat $t_{\text {hit }}=9,69$ kategori sedang dan $t_{t a b}=2,05$ maka $t_{\text {hit }}>t_{t a b}$ artinya penelitian ini berhasil. Pembelajaran dengan menggunakan media komik sains secara tidak langsung, siswa mengembangkan ketrampilan berupa kritis, kreatif, kolaboratif dan komunikatif sesuai dengan tuntutan abad 21.

\section{Saran}

Adapun saran yang disampaikan berdasarkan hasil penelitian ini adalah agar guru pada bidang studi atau mata pelajaran lainnya dapat mengimplementasikan media komik sains ini dengan melakukan modifikasi dari aspek yang lainnya.

\section{DAFTAR PUSTAKA}

Arsyad, Azhar. (2011). Media Pembelajaran. Jakarta : PT. Raja Grafindo Persada.

Daryanto. (2010). Media Pembelajaran. Yogyakarta : Gava Media.

Hamalik, Oemar. (2004). Proses Belajar Mengajar, Jakarta : Bumi Aksara

Muh. Syukri Ahsani. (2015) PEMBELAJARAN IPA BERBASIS INKUIRI BERBANTUAN KOMIK SAINS UNTUK MENGEMBANGKAN KARAKTER SISWA. Under Graduates thesis, Universitas Negeri Semarang.

Musfiqon. (2012). Pengembangan Media dan Sumber Pembelajaran. Jakarta: Prestasi Pustaka.

Munandar, Utami. (2005). Mengembangkan Bakat dan Kreativitas Anak Sekolah. Jakarta: PT Gramedia Widiasarana.

Nurlatipah, N., Juanda, A., \& Maryuningsih, Y. (2015). PENGEMBANGAN MEDIA PEMBELAJARAN KOMIK SAINS YANG DISERTAI FOTO UNTUK MENINGKATKAN HASIL BELAJAR SISWA KELAS VII SMPN 2 SUMBER PADA POKOK BAHASAN EKOSISTEM. Scientiae Educatia: Jurnal Pendidikan Sains, 4(2). doi:http://dx.doi.org/10.24235/sc.educatia.v4i2.491

Purwati, N. (2019). Upaya Meningkatkan Motivasi dan Hasil Belajar IPA Siswa Melalui Penerapan Model Pembelajaran STAD di Kelas VI SD Negeri 42 Mataram. Jurnal Paedagogy, 6(1), 14-19. doi:https://doi.org/10.33394/jp.v6i1.2525

Setiarini, A. (2016). Meningkatkan Motivasi dan Hasil Belajar Peserta Didik dengan Mengoptimalkan Penerapan Pendekatan Saintifik Strategi Discovery Learning dan Metode Diskusi di SDN Model Mataram. Jurnal Kependidikan: Jurnal Hasil Penelitian dan Kajian Kepustakaan di Bidang Pendidikan, Pengajaran dan Pembelajaran, 2(1). doi:https://doi.org/10.33394/jk.v2i1.390

Soekarman, S. (2021). Impementasi Pembelajaran Fisika Pokok Bahasan Elastisitas Melalui Inquiry Based Learning di SMA Negeri 2 Donggo. Jurnal Paedagogy, 8(2), 197-209. doi:https://doi.org/10.33394/jp.v8i2.3521

Suarni, G., Rizka, M., \& Zinnurain, Z. (2021). Analisis Pengaruh Penerapan Model Pembelajaran Sains Teknologi Masyarakat Terhadap Hasil Belajar Siswa. Jurnal Paedagogy, 8(1), 31-38. doi:https://doi.org/10.33394/jp.v8i1.3226 